\title{
Investimento Direto Externo no Brasil: uma análise para o período de alta inflação *
}

\author{
Marcelo Curado ** \\ Márcio Cruz ${ }^{* * *}$
}

\begin{abstract}
Resumo
Este artigo discute o comportamento do investimento direto externo no Brasil no período que se estende de 1980 a 1994. Seguindo a proposta metodológica originalmente desenvolvida por Castro (1979) e Possas (1983), o artigo apresenta a evolução do Investimento Direto Externo (IDE) no país como reflexo das condições vigentes no plano doméstico e no plano internacional. Com base em tal abordagem, procura-se demonstrar que as condições vigentes na década de 1980 não foram favoráveis à expansão dos IDEs no Brasil. Ademais, o período marca uma transição importante no papel e na composição setorial dos IDEs no país, acompanhando mudanças econômicas, tecnológicas e políticas no âmbito doméstico e internacional.
\end{abstract}

Palavras-chave: Economia brasileira; Investimento Direto Externo; Alta inflação.

\begin{abstract}
Foreign Direct Investment in Brazil: an anlysis of the high inflation period

This paper discusses the performance of foreign direct investment in Brazil between 1980 and 1994, a period highlighted by high inflation in the economy. Following the methodology originally developed by Castro (1979) and Possas (1983) the article presents the evolution of FDI in the country as a reflection of domestic and international conditions. Based on this approach, the authors argue that during the 1980s these conditions were not conducive to the expansion of FDI in Brazil. In addition, this period marks an important transition in the role and sector composition of FDI, at the same time as critical economic, technological and political changes, from both a Brazilian and international perspective, were taking place.
\end{abstract}

Keywords: Brazilian economy; Foreign Direct Investment; High inflation.

JEL F21.

\section{Introdução}

A década de 1980 e o início dos anos 1990 foram marcados no plano internacional por profundas transformações econômicas. O aprofundamento das relações comerciais entre as nações, o vertiginoso crescimento dos fluxos de capitais especulativos e o acirramento da competição em nível global das grandes empresas multinacionais (EMNs) são elementos centrais deste processo, genericamente denominado de "globalização".

\footnotetext{
* Trabalho recebido em 26 de julho de 2010 e aprovado em 11 de março de 2011.

** Professor da Universidade Federal do Paraná (UFPR), Curitiba, SP, Brasil. E-mail :<mcruz@ufpr.br>..

*** Professor Associado da Universidade Federal do Paraná (UFPR) e Pesquisador do Programa "Cátedras para o Desenvolvimento” do Instituto de Pesquisa Econômica Aplicada (IPEA). E-mail: <curado@ufpr.br>
} 
No plano doméstico, o período foi marcado pelo "esgotamento do padrão de desenvolvimento" da economia brasileira. A brutal redução no ritmo de crescimento do produto, particularmente do derivado das atividades industriais e o descontrole do processo inflacionário são as faces mais evidentes da chamada "década perdida".

Este artigo analisa o comportamento dos investimentos diretos externos (IDEs) na economia brasileira no período de alta inflação (1980-1994), com ênfase na discussão na década de 1980, a chamada "década perdida". Seu objetivo central é entender os movimentos do capital produtivo para a economia brasileira à luz das condições vigentes no plano doméstico e na economia internacional, seguindo, portanto, as contribuições teóricas de Castro (1979) e Possas (1983) sobre o tema ${ }^{1}$.

Além da discussão sobre os determinantes do comportamento dos fluxos de IDE para o país, o trabalho também pretende contribuir na análise dos impactos dos IDEs sobre a estrutura produtiva e o Balanço de Pagamentos. Finalmente, ao analisar as alterações processadas no comportamento dos IDEs, o artigo pretende promover uma discussão mais ampla quanto ao "colapso do padrão de desenvolvimento" brasileiro, deixando claro o papel do capital produtivo internacional na configuração da "década perdida".

É importante ressaltar que as discussões sobre o IDE no Brasil para esse período são relativamente escassas, sobretudo quando comparadas com volume de trabalhos existentes para o período posterior ao processo de estabilização da economia brasileira. $\mathrm{O}$ artigo contribui, portanto, para ampliação do debate sobre o comportamento e os impactos dos IDEs na economia brasileira a um período relativamente pouco explorado pela literatura econômica.

Encontra-se estruturado da seguinte forma: após breve introdução, a seção 1 apresenta o referencial teórico utilizado no trabalho e a seção 2, uma seleção de contribuições da literatura econômica brasileira sobre o tema. A seção 3 é dedicada à análise das condições internas da economia brasileira. A seção 4 aborda a caracterização do cenário econômico internacional, com foco no comportamento do IDE em nível global. A seção 5 analisa o comportamento do IDE no Brasil para o período que se estende de 1980 a 1994. A seção 6 compara a magnitude do IDE e analisa seus efeitos com relação às Transações Correntes, com base nos resultados do Balanço de Pagamentos. Finalmente, a última seção apresenta as conclusões finais do estudo.

(1) Em essência, estes trabalhos argumentam que os movimentos do capital produtivo a um determinado país refletem, em grande medida, as condições vigentes na economia mundial, assim como as condições internas de acumulação. O tema será discutido com maior profundidade na seção 1 do trabalho 


\section{Movimentos do capital produtivo e as condições internas e externas de acumulação}

A discussão teórica sobre os determinantes dos movimentos do capital produtivo em nível internacional é ampla e encontra-se além do escopo deste trabalho. Cantwell (1990) apresenta uma síntese das principais contribuições sobre o tema, com destaque para a análise da teoria do poder de mercado de Hymer (1976), a teoria da internalização desenvolvida a partir das contribuições originais de Williamson (1975) e do paradigma eclético desenvolvido por Dunniing (1979)².

O artigo utiliza como referencial teórico as contribuições originalmente desenvolvidas em Castro (1979) e Possas (1983). A ideia central dos autores mostra que os movimentos do capital produtivo para a economia brasileira refletem, em grande medida, as condições internas e externas de acumulação de capital. Em síntese, argumenta-se que a compreensão dos movimentos do capital produtivo em nível internacional deve levar em consideração as condições históricas concretas, tanto no plano doméstico, quanto no plano externo. Castro (1979) deixa claro este ponto:

Partiremos da premissa de que as características assumidas pelo investimento estrangeiro no país são o resultado de uma dupla determinação: de um lado a expansão das economias centrais passava, necessariamente, pela exportação de capitais; de outro lado, o crescimento e diversificação da economia brasileira propiciavam oportunidades atraentes, que seriam aproveitadas por investidores estrangeiros. Em outras palavras, realçamos o permanente surgimento de oportunidades de investimento derivadas das transformações em curso na economia brasileira e aproveitadas pelas empresas estrangeiras (Castro, 1979, p. 11).

Possas (1983) segue a mesma linha de raciocínio apresentada por Castro (1979). De acordo com o autor:

Tanto em relação à origem quanto ao setor de destino do investimento direto estrangeiro no Brasil, é importante levar em conta ao mesmo tempo as condições internas e os determinantes externos, assim como os vínculos entre eles. Essa visão distingue-se de outras, mais comuns, que focalizam o investimento estrangeiro, seja num contexto de modernização do país receptor, seja sob a perspectiva limitada de rentabilidade dos negócios e remessas de lucros. A conexão peculiar entre os determinantes internos e externos seria assim responsável pelas características assumidas pelo investimento direto estrangeiro em cada período considerado (Possas, 1983, p. 9).

Em síntese, o referencial teórico escolhido argumenta que os movimentos do capital produtivo devem ser entendidos como resultantes da conjunção de condições vigentes na economia internacional e das condições internas de acumulação. Enfatiza, portanto, que o entendimento do comportamento do IDE deverá levar em consideração as condições históricas concretas vigentes nos planos internacional e

(2) Para uma revisão, com a incorporação de trabalhos mais recentes sobre o tema, sugere-se a leitura de Curado e Cruz (2008). 
local. Considera, em última análise, que os movimentos do IDE decorrem de um processo dinâmico, no qual história e instituições importam.

A utilização do citado referencial teórico para o entendimento dos movimentos do IDE a um país implica analisar as condições vigentes na economia local, assim como as condições da economia internacional, especialmente, a caracterização dos movimentos do capital produtivo em escala global. Tais análises são realizadas nas respectivas seções 3 e 4 do trabalho. Antes, no entanto, é importante apresentar a discussão da literatura econômica brasileira ao período.

\section{Contribuições da literatura}

Não é objetivo desta seção promover uma revisão completa e exaustiva da literatura. Pretende-se apenas posicionar o presente artigo em relação a um conjunto selecionado - e reconhecidamente limitado - de contribuições sobre o tema, tornando-o assim mais evidente em sua especificidade.

Fristch e Franco (1989), por exemplo, discutem o tema do IDE para os anos 1980 de uma perspectiva normativa. Seu objetivo central é apresentar as principais linhas de uma política de atração do capital estrangeiro, particularmente o IDE. Trata-se de um trabalho de caráter normativo, cujo foco não se encontra no estudo dos determinantes dos fluxos de capital produtivo ao país. A principal contribuição dos autores para o debate encontra-se em demonstrar a importância do tratamento ao capital estrangeiro enquanto um componente relevante de uma estratégia de desenvolvimento econômico.

Bielschowsky (1992) estuda os motivos para o capital estrangeiro não desistir de produzir no país, apesar da reconhecida perda de relevância do Brasil a novos investimentos. De acordo com o autor, os elevados sunk costs envolvidos nas operações das EMNs - fruto dos pesados investimentos realizados nas décadas passadas - e o potencial de crescimento futuro do mercado brasileiro são essenciais para entender a permanência dos interesses estrangeiros no país.

Gonçalves (1993) identifica a ocorrência de profundas transformações na estratégia das grandes empresas multinacionais (EMNs) ao longo dos anos 1980 no Brasil. No cenário de crise interna, as EMNs optaram por políticas de redução de custos e de pessoal ocupado e buscaram no mercado externo, por meio da ampliação de suas exportações, uma saída para a redução da demanda doméstica.

Tal estratégia de redução de custos e busca de mercados externos ocorreu concomitantemente a uma política de redução dos investimentos líquidos, elemento que contribuiu para a ampliação do atraso tecnológico e organizacional das subsidiárias das EMNs operando no Brasil. Outro elemento importante diz respeito à estratégia financeira das EMNs no período, com destaque ao incremento dos lucros financeiros dessas empresas no país. 
Assim, de acordo com Gonçalves (1993), deve-se destacar o caráter "defensivo" da estratégia das EMNs no Brasil durante os anos 1980. De acordo com o autor, dois aspectos explicam a reação estratégica "defensiva": i) a permissividade do mercado interno, ii) a política de estabilização macroeconômica adotada no período.

No caso particular do Brasil, há dois fatores que são fundamentais para explicar a reação estratégica das empresas transnacionais no país, assim como a competitividade internacional da economia brasileira. Estes determinantes estruturais são o grau de permissividade do mercado interno e a política de estabilização macroeconômica adotada. A permissividade do mercado interno pode ser entendida na dupla ausência de mecanismos de seletividade em relação aos investimentos estrangeiros e de compromissos de desempenho, incluídos aí os de uma política de concorrência (Gonçalves, 1993, p. 4-5).

No que tange especificamente ao papel das políticas de estabilização adotadas e seus impactos sobre as estratégias empresariais, o autor destaca que a manutenção de elevadas taxas de juros reais permitiram às EMNs, assim como às empresas nacionais, implementar uma estratégia de aumento dos lucros de natureza financeira, elemento que funcionou como uma "válvula de escape" para a realização do capital e a geração de lucro.

Cunha (1995) analisa o padrão de inserção do IDE no Brasil nos anos 1980 e início da década de 1990. Entre outros elementos, vale a pena destacar a investigação promovida pelo autor sobre a hipótese - defendida entre outros por Gonçalves (1993) - de ocorrência de um comportamento "defensivo" das EMNs na década de 1980. Ao estudar um amplo conjunto de empresas, ou seja, ao incorporar ao debate o nível setorial e a dinâmica microeconômica, o autor conclui que a hipótese geral de ajuste defensivo exprime o comportamento de uma parcela dos setores analisados. Outros setores, como por exemplo, os de "processo contínuo de recursos naturais", não se enquadrariam na hipótese de ajuste defensivo.

Laplane e Sarti (1997) discutem o papel do IDE para uma retomada do crescimento econômico sustentado nos anos 1990. Seu argumento central é que o poder de indução de crescimento dos IDEs era baixo. O trabalho demonstra, portanto, os limites de uma estratégia de crescimento econômico induzido pelos fluxos de IDE. O foco encontra-se, portanto, em explorar o comportamento dos IDEs nos anos 1990 e, particularmente, sua capacidade de promoção de crescimento econômico.

Franco (1998) discute, entre outros temas, o comportamento dos IDE nos anos 1980 e na primeira metade dos anos 1990. A principal conclusão do autor é que a instabilidade econômica vigente no período de alta inflação e a manutenção de um padrão de desenvolvimento centrado no modelo de substituição de importações são os principais responsáveis pela redução dos fluxos de IDEs para o Brasil. O foco do trabalho, no entanto, encontra-se em anunciar a alteração no comportamento 
dos IDEs ao país a partir do processo de estabilização. Para o autor, a retomada da importância dos IDEs desempenharia papel fundamental na elevação da produtividade da economia e, assim, de sua competitividade externa, peça fundamental do novo padrão de desenvolvimento econômico inaugurado com o Plano Real.

Sarti e Laplane (2002), por sua vez, analisam o processo de internacionalização produtiva da economia brasileira nos anos 1990 destacando a existência de profundas diferenças entre a experiência brasileira e o que ocorreu em outros países, com destaque para o México, Coréia do Sul e China. O foco do trabalho encontrase na comparação do comportamento do IDE no Brasil com outras experiências internacionais selecionadas.

Nonnenberg (2003) promove uma ampla revisão dos movimentos dos IDEs para o Brasil. Seu foco, no entanto, encontra-se na comparação entre os movimentos do capital produtivo nos anos 1970 e nos anos 1990. Há uma clara concentração dos esforços do autor no sentido de analisar esses dois momentos particulares, deixando em segundo plano a análise específica dos anos 1980.

Finalmente, Mattos, Cassuce e Campos (2007) analisam os determinantes dos IDEs para o Brasil no período que se estende de 1980 a 2004. O trabalho utiliza o instrumental econométrico para selecionar variáveis que, de acordo com os autores, explicariam o comportamento dos fluxos de IDE para o Brasil. O risco-país, o grau de abertura da economia e a taxa de inflação são as variáveis mais importantes para explicar o comportamento dos fluxos de IDE para o Brasil.

Os textos selecionados na seção permitem verificar a existência de uma profunda diversidade temática em relação ao estudo do IDE para o período. As preocupações dos autores abrangem um amplo espectro que vai desde a discussão sobre os determinantes do IDE até a proposição de políticas de atração para o capital produtivo ou ainda a discussão sobre o potencial de indução do crescimento de tais investimentos. Este artigo busca contribuir com a discussão em dois planos essenciais: i) demonstrando que os movimentos do capital produtivo para o Brasil refletem as condições vigentes no plano doméstico e no plano internacional, ii) apresentando evidências, em grande medida trabalhadas apenas marginalmente pela literatura, de que a década de 1980 presenciou mudanças relevantes no comportamento dos investimentos produtivos estrangeiros no Brasil, mudanças que foram intensificadas a partir do processo de estabilização econômica dos anos 1990.

\section{Considerações sobre o cenário doméstico}

Esta seção apresenta as principais características da economia brasileira no período, não como um objetivo em si, mas como marco de referência central para a análise do comportamento dos fluxos de capital produtivo para o país. 
No plano doméstico, a década de oitenta foi marcada pela profunda retração no ritmo de crescimento do produto e pela aceleração do processo inflacionário ${ }^{3}$. $\mathrm{O}$ Gráfico 1 demonstra o desempenho relativo ao PIB per capita estagnado e o nível de inflação crescente entre 1980 e 1994, processo que ficou conhecido na literatura econômica como um período de "estagflação" como referência à combinação de dois fenômenos indesejáveis: estagnação econômica e hiperinflação.

Gráfico 1

PIB per capita e Inflação (IPC - \% a.a) no Brasil entre 1980 e 1994

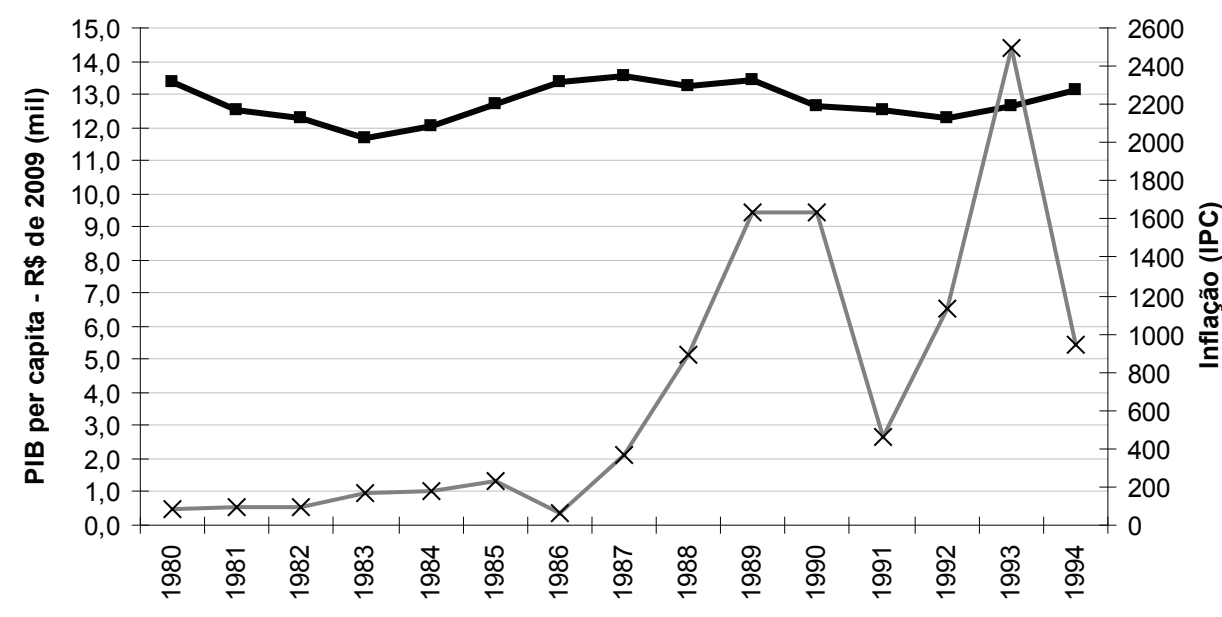

-PIB per capita (preços 2009) - R\$ de 2009(mil)

X Inflação - IPC (FIPE) - (\% a.a.)

Fonte: Elaboração própria com base em IPEA (2010) e FIPE (2010), disponível em IPEADATA (2010) .

Entre 1981 e 1983 a preocupação central dos formuladores da política econômica encontrava-se na solução do desequilíbrio externo. A combinação de políticas fiscais e monetárias contracionistas, além das desvalorizações da taxa de câmbio nominal, constituiu-se no núcleo da política econômica do período. Seu objetivo central era promover o ajuste das contas externas por meio da contração da demanda agregada interna. $\mathrm{O}$ ajuste do balanço de pagamentos, particularmente o resultado obtido em 1984, como resultado do megasuperávit comercial daquele ano e a aceleração do processo inflacionário promoveram a mudança de foco da política econômica do estrangulamento externo para o combate ao processo inflacionário, em um cenário de reduzido crescimento do produto.

(3) O PIB per capita brasileiro em 1980 era aproximadamente 2,31 vezes maior do que o de 1965 . A taxa média de crescimento entre 1966 e 1980 foi de 5,8\%. Esse indicador era 1,7\% menor em 1994, com uma taxa média de crescimento negativa de -(0,05\%) entre 1981 e 1994 . Não bastasse o cenário de estagnação presente na economia brasileira durante esse período, a inflação que já havia alcançado o patamar de três dígitos em 1980 (IPC foi de 110\% a.a.), nível suficiente para caracterizar um processo de hiperinflação, atingiu níveis exorbitantes entre a segunda metade da década de 1980 e a primeira da década de 1990, ultrapassando quatro dígitos anuais (IPC de 1.636\% a.a em 1989 e $2.490 \%$ a.a em 1993). 
Cenário o qual colocava em xeque a capacidade dos instrumentos convencionais de contenção do nível de preços por meio de política monetária ou fiscal restritivas. Afinal de contas, a primeira metade da década de 1980 já era marcada por uma taxa média de crescimento negativa, o que estimulou e fortaleceu o surgimento de teses inercialistas e de soluções heterodoxas para o combate à inflação. A partir de então, até o ano de 1994, o Brasil recorreu a diversos planos de estabilização e reforma monetária na tentativa, por diversas vezes frustradas, de alcançar e estabilidade monetária.

Os anos 1980 foram marcados, portanto, por turbulências econômicas que afetaram toda uma geração a qual conviveu por uma década e meia, entre 1980 e 1994, com o fenômeno da "estagflação". Não bastasse esse cenário de estagflação, que por si só já seria um grande desafio a ser enfrentado, havia uma transição política importante sendo conduzida no país, o que ampliava o grau de incerteza institucional no curto prazo.

É bom lembrar que o Brasil iniciou a década de 1980 ainda sob o domínio do regime militar, substituído pelo voto indireto em 1985. Em tal fase foi elaborada a nova constituição em 1988 e assistiu-se ao retorno do regime democrático baseado no voto direto em 1989. O início da década de noventa não alterou profundamente o citado cenário. Nesse ano, foi empossado o primeiro presidente eleito por meio do voto direto na nova república "deposto" do cargo em meio à abertura de um processo de impeachment.

Em síntese, a instabilidade econômica e política que marcaram o período entre 1980 e 1994 tornaram a economia brasileira pouco atrativa para o investimento estrangeiro direto.

Dois aspectos devem ser destacados ainda sobre o contexto doméstico tendo vista sua importância ao comportamento dos fluxos de IDE para o país. Em primeiro lugar, é importante ressaltar que a crise dos anos 1980 é, em grande medida, do setor industrial. De acordo com Suzigan (1992), durante toda a década de 1980, a indústria manufatureira no Brasil cresceu apenas 0,2\% em termos reais, o que evidencia o duro golpe sobre o desenvolvimento da indústria durante a década perdida. Vale lembrar que o longo período compreendido entre 1955-1980 foi marcado, seguindo entre outros Possas (1983), pela concentração dos IDEs em atividades da indústria manufatureira, particularmente nos setores dinâmicos do paradigma tecnológico metalmecânico-químico.

Finalmente, é importante destacar que a crise dos anos 1980 simboliza mais do que um processo de estagflação clássico. Ela marca o colapso de um "padrão de desenvolvimento" estruturado em uma clara divisão do trabalho entre o capital privado nacional, o capital privado internacional e o Estado. A crise fiscal do 
Estado brasileiro e a redução de sua capacidade de investir, assim como o processo de ajuste patrimonial empreendido pelo capital privado nacional são fenômenos extensivamente discutidos pela literatura econômica brasileira. O estudo do comportamento do capital produtivo estrangeiro no período de alta inflação, tema da seção 5, tornará evidente sua contribuição para o acirramento da crise, assim como para o aprofundamento da distância tecnológica entre o Brasil e o resto do mundo.

\section{Considerações sobre o cenário internacional}

No plano externo, o acirramento da competição entre as EMNs é o principal fenômeno a ser destacado, tendo em vista os objetivos deste trabalho. O ponto de partida da discussão é a resposta das políticas monetária e cambial dos Estados Unidos frente ao primeiro choque do petróleo de 1973 e seus impactos sobre as condições de concorrência em nível global

Entre 1973 e 1979, a política de ajuste do Balanço Pagamentos norteamericano foi centrada na reversão dos déficits comerciais norte-americanos por meio da promoção de uma política de desvalorizações graduais do dólar. A fuga de capital, no entanto, fruto dessa política cambial e da continuidade do processo de internacionalização das EMNs norte-americanas, tornaram o ajuste via balança comercial ineficaz frente aos resultados obtidos na conta capital e financeira

Em 1979, em função do fracasso do processo ajuste do balanço de pagamentos via política de softlanding do dólar e das pressões inflacionárias derivadas do segundo choque do petróleo, observou-se a reversão da política monetária e cambial norteamericana e das demais economias desenvolvidas que acompanharam - de forma relativamente alinhada - as medidas de elevação das taxas de juros e de valorização do dólar norte-americano.

De acordo com Baer (1990) a saída encontrada pelo Federal Reserve (FED) foi alterar a estratégia, concentrando esforços na obtenção de superávits na conta capital e financeira, por meio da promoção de uma política monetária fortemente contracionista. Além de promover a entrada de capitais e com isso ajustar o Balanço de Pagamentos, a elevação das taxas de juros no mercado norte-americano promovia a contração da demanda agregada doméstica necessária, nesse momento, para fazer frente às pressões inflacionárias derivadas do segundo choque do petróleo

Por fim, a entrada de capital e a consequente valorização do dólar cumpriam igualmente um duplo papel: ajudar no combate ao processo inflacionário pelo pass-trought cambial e retomar o papel do dólar como divisa internacional, papel sensivelmente debilitado após o colapso de Bretton Woods e a política de "negligência benigna" que permitiu uma lenta e contínua desvalorização da moeda norte-americana entre 1973 e 1979. 
Segundo Tavares (1992), a "política do dólar forte" foi também relevante na determinação de um movimento recessivo da economia mundial, em especial nos países em desenvolvimento, como consequência da elevação dos encargos financeiros do endividamento externo de tais países, que passaram a transferir parcelas significativas de suas divisas aos países credores.

Do ponto de vista deste trabalho, é importante destacar que a política de valorização do dólar no início dos anos 1980 colaborou para a perda de competitividade do sistema industrial norte-americano em nível internacional, processo que já se verificava desde meados da década de 1960 como resultado do catching up tecnológico empreendido pelas grandes empresas alemãs e japonesas. Em outras palavras, a "política do dólar forte" foi um ingrediente importante para o acirramento da competição comercial em nível global.

Em 1985, as políticas monetárias e cambiais norte-americanas foram novamente alteradas. A partir de então, assistiu-se à redução da taxa de juros e desvalorizações do dólar norte-americano. A política, consolidada no "acordo de Plaza", tinha um duplo objetivo. Em primeiro lugar, reduzia os encargos financeiros do Estado americano, comprometido pela política monetária restritiva implementada pelo FED desde 1979. Em segundo lugar, buscava elevar a competitividade do setor exportador - comprometido pela valorização cambial do período 1979-1985 - revertendo, assim, o profundo desequilíbrio em transações correntes norteamericanas.

O enfraquecimento do dólar e a valorização relativa do iene observada a partir de 1985 - somado ao processo de catching up tecnológico empreendido pelas empresas japonesas desde os anos 1960 - foi um ingrediente relevante para a compreensão de um dos mais importantes fenômenos econômicos da década de 1980, quer seja à entrada das multinacionais japonesas no mercado norte-americano.

Os movimentos das políticas monetária e cambial dos EUA durante o final dos anos 1970 e durante os anos 1980, somados aos esforços de aumento de competitividade empreendidos pelas grandes empresas multinacionais japonesas e alemãs desde meados dos anos 1960 resultaram em um processo de acirramento da competição em nível global. Em síntese, após o movimento original de expansão das grandes multinacionais norte-americanas no pós-guerra, observou-se um processo de internacionalização de grandes empresas de outros países, particularmente de origem japonesa e alemã. O resultado do processo foi o que Coutinho (1992), entre outros, denominou de "acirramento da competitividade internacional".

Finalmente, deve-se destacar, em função dos objetivos do trabalho que, seguindo as tendências já visualizadas na década de 1970, os anos 1980 assistem 
à consolidação do Complexo Eletrônico enquanto eixo dinâmico da atividade industrial. Nesse sentido, deve-se destacar inicialmente o crescimento do "peso" do Complexo Eletrônico nas estruturas industriais dos países desenvolvidos. Fajnzyber (1989) aponta que, na economia norte-americana, o complexo já superava no final dos anos 1980, o complexo automobilístico e químico em termos de valor nas vendas

Coutinho (1992) e Laplane (1992) destacam ainda que os setores do Complexo Eletrônico constituem-se no eixo irradiador do progresso técnico pelo setor industrial. Assim, a capacidade inovativa dos demais setores industriais encontra-se diretamente vinculada ao ritmo de inovações determinado no interior do Complexo Eletrônico. Outro aspecto que merece destaque é que a introdução de tecnologia de base microeletrônica em setores tradicionais ou caracterizados pela base tecnológica metalmecânica promoveu a revitalização, no sentido de retomada das taxas de crescimento, de setores "maduros".

Diversos elementos devem ser destacados no que tange especificamente aos movimentos do capital produtivo em escala global. Em primeiro lugar, é preciso chamar atenção ao crescimento sem precedentes dos fluxos de IDE em nível global. Entre 1983 e 1989, o IDEs nos países da Organização para Cooperação e Desenvolvimento Econômico (OCDE) cresceu a taxa média anual de 31,4\%, aproximadamente três vezes mais que o comércio (11\% ao ano), a Formação Bruta de Capital Fixo (11,9\% ao ano) e o Produto Nacional Bruto (10,4\% ao ano). Para se ter uma ideia do significado dessa expansão, basta assinalar que do estoque mundial de IDE de US\$1,7 trilhão no final de 1990, mais de US\$ 800 bilhões concretizaramse entre 1985 e 1990.

Tal expansão do capital produtivo em nível global é uma das faces mais importantes do processo de mundialização do capital, de acordo com Chesnais (1996). O brutal crescimento das transações de natureza comercial, dos fluxos de capital produtivo e das transações financeiras resulta, em sua essência, de dois movimentos interligados, ainda que distintos. De acordo com o autor:

A mundialização é o resultado de dois movimentos conjuntos, estreitamente interligados, mas distintos. O primeiro pode ser caracterizado como a mais longa fase de acumulação ininterrupta do capital que o capitalismo conheceu desde 1914. O segundo diz respeito às políticas de liberalização, de privatização, de desregulamentação e de desmantelamento de conquistas sociais e democráticas, que foram aplicadas desde o início da década de 80, sob o impulso dos governos Thatcher e Reagan... sem a implementação de políticas de desregulamentação, de privatização e de liberalização do comércio, o capital financeiro internacional e os grandes grupos multinacionais não teriam podido destruir tão depressa e tão radicalmente os entraves e freios à liberdade deles de se expandirem à vontade e de explorarem os recursos econômicos, humanos e naturais, onde lhes for conveniente (Chesnais, 1996, p. 34). 
Assim, a mundialização do capital - da qual a expansão do capital produtivo em nível internacional é um elemento fundamental - deve ser entendida não só como o resultado do processo de acumulação de capital originado durante as "décadas douradas" do capitalismo e sua necessidade de expansão para manutenção do processo de valorização, bem como do conjunto de políticas de liberalização, privatização e desregulamentação que permitiram ao capital internacional promover inversões "onde lhes for conveniente".

Outro elemento que merece destaque é o aumento da importância dos IDEs em fusões e aquisições. De acordo com Canuto (1993), entre 1982-1988, os IDEs norte-americanos em novos estabelecimentos somaram cerca de US\$ 58 bilhões, enquanto as aquisições/fusões representaram US\$ 300 bilhões.

Deve-se enfatizar também, como característica marcante do padrão recente de expansão do capital produtivo, a predominância dos IDEs nos setores de serviços vis-à-vis sua concentração em atividades manufatureiras que caracterizavam a expansão do período precedente. Até 1970, o setor de serviços representava cerca de $25 \%$ do total do estoque de IDE no mundo. Em 1980, esta participação saltou para cerca de $50 \%$, desses fluxos.

De acordo com Chesnais (1996), o crescimento dos fluxos de IDE para o setor de serviços deverá ser entendido no contexto dos processos de liberalização e desregulamentação que marcaram o período. De acordo com o autor:

...o florescimento contemporâneo do IDE nos serviços tem motivos ainda mais poderosos. No caso das grandes infra-estruturas [sic], que foram organizadas, na maioria dos países, com base no serviço público, bem como no setor financeiro, era necessário que o movimento de liberalização e desregulamentação estourasse o ferrolho das limitações das legislações nacionais... Visto sob o ângulo das necessidades do capital concentrado, o duplo movimento de desregulamentação e de privatização dos serviços públicos constitui uma exigência que as novas tecnologias vieram atender sob medida (Chesnais, 1996, p. 186).

Finalmente, chama atenção o crescimento dos investimentos produtivos de origem alemã e, em particular, japonesa no mercado norte-americano, fenômeno que simboliza o processo de acirramento da competitividade em nível global durante a década de oitenta.

Em síntese, os anos 1980 e a primeira metade da década de 1990 foram marcados no plano internacional pelo acirramento da competição em nível global, que concretamente se traduziu em uma fase de expansão significativa dos investimentos das grandes EMNs em escala global. Isso, com destaque para a ampliação da participação das economias japonesas e alemãs enquanto exportadoras 
de capital produtivo e o aumento da participação dos EUA enquanto área de destino dos investimentos, sobretudo a partir de 1985. Por fim, tais investimentos dirigiramse essencialmente às atividades de serviços na forma de fusões e aquisições de empresas preexistentes.

\section{Comportamento do IDE no Brasil (1980-1994)}

O objetivo desta seção é analisar o comportamento do capital produtivo estrangeiro no Brasil no período selecionado. Se do ponto de vista dos fluxos globais de IDE, a década de 1980 foi marcada por uma expansão sem precedentes, no plano doméstico, pode-se afirmar que a economia brasileira ficou à margem do citado processo, conforme demonstrado pelo Gráfico 2.

Gráfico 2

Investimento Direto Externo líquido (ingresso) em US\$ milhões: 1980-1994

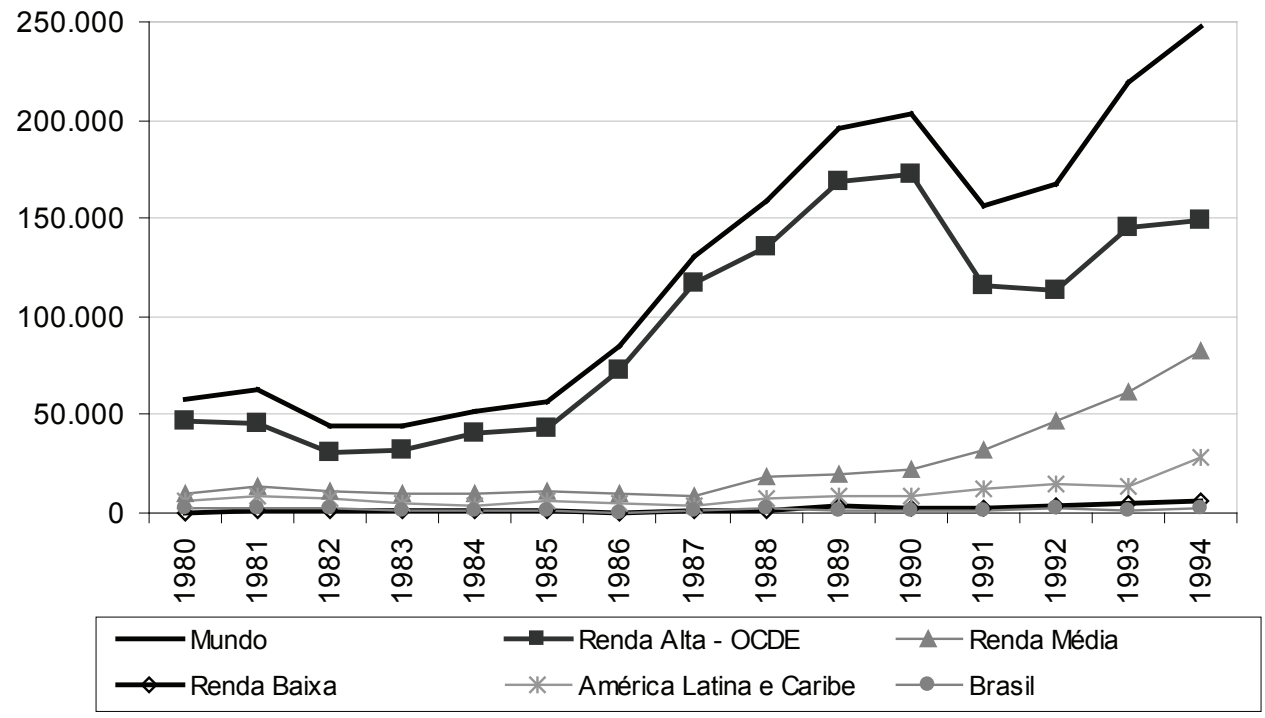

Fonte: Elaboração própria com base em WDI, World Bank (2007).

De acordo com o Gráfico 2, observa-se que a maior parte de IDE entre 1980 e 1994 teve, como destino, os países de alta renda ${ }^{4}$ - de acordo com o critério de classificação do Banco Mundial, pertencentes à OCDE. Ademais, constata-se que, a partir do final da década de 1980, houve uma expansão expressiva de países de renda média.

(4) Países de alta renda membros da OCDE: Austrália, Áustria, Bélgica, Canadá, Dinamarca, Finlândia, França, Alemanha, Grécia, Islândia, Irlanda, Itália, Japão, Coreia do Sul, Luxemburgo, Holanda, Nova Zelândia, Noruega, Portugal, Espanha, Suécia, Suíça, Estados Unidos e Reino Unido (World Bank, 2007). 
O Brasil, entretanto, manteve-se à margem do processo de expansão de IDE ao longo de todo o período. Em 1978 e 1979 os fluxos líquidos de IDE ao país alcançaram, respectivamente, US\$ 2,18 e US\$ 2,40 bilhões, valores superiores à média registrada durante toda a década de 1980. De acordo com o Gráfico 3, a queda nos fluxos de IDE para o país foi particularmente acentuada a partir de 1982, com recuperação dos fluxos somente a partir do 1987. Considerando-se o lapso temporal entre a decisão investir e sua realização, é possível argumentar que a retração dos fluxos de IDE para o país entre 1982-1986 reflete a crise econômica interna de 19811983. Na mesma linha de raciocínio, a recuperação dos fluxos de IDE para o país no biênio 1987-1988 resultou do miniciclo de expansão da economia brasileira entre 1984-1986.

Gráfico 3

Investimento Direto Externo líquido* no Brasil em US\$ milhões: 1980-1994

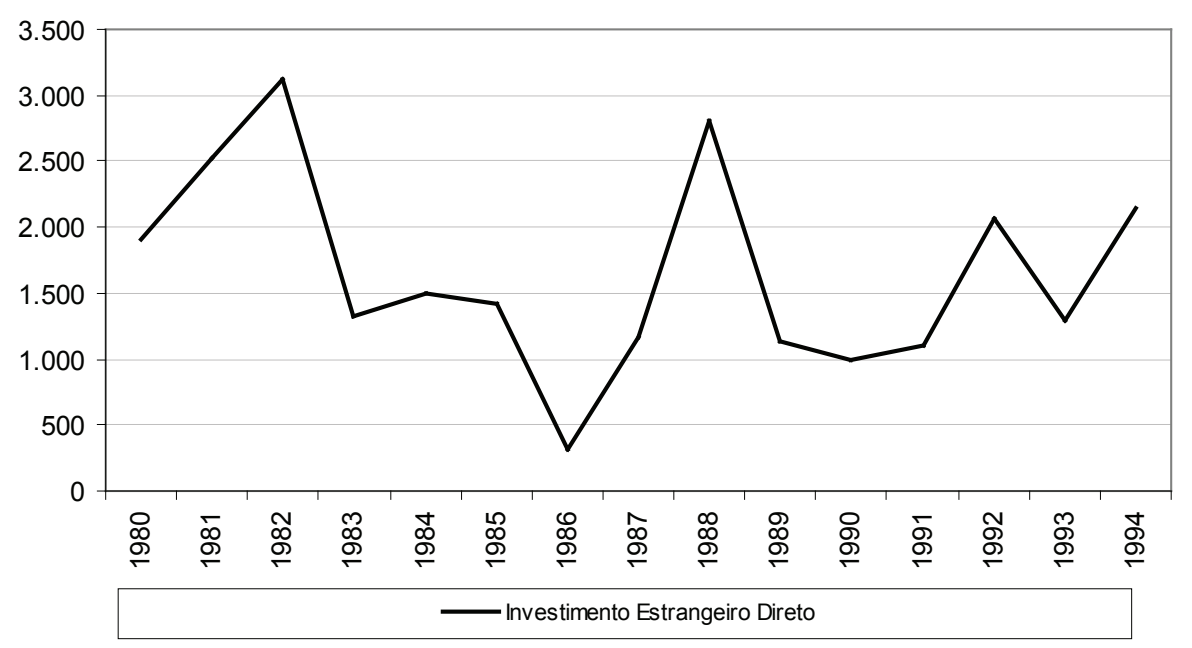

*Inclui reinvestimentos

Fonte: Banco Central do Brasil - Balanço de Pagamentos.

Outro aspecto relevante do comportamento do capital produtivo na economia brasileira diz respeito à concentração setorial dos investimentos estrangeiros. A Tabela 1 apresenta a distribuição setorial do estoque de capital estrangeiro em 1980 e 1990. 
Tabela 1

Distribuição setorial do estoque de capital estrangeiro no Brasil (1980 e 1990) em US\$ milhões

\begin{tabular}{|c|c|c|c|c|}
\hline Setor/Ramo de Atividade & $\operatorname{dez} / 1980$ & $\begin{array}{c}\% \text { do } \\
\text { Estoque } \\
\text { Total }\end{array}$ & $\operatorname{dez} / 1990$ & $\begin{array}{c}\%) \text { do } \\
\text { Estoque } \\
\text { Total } \\
\end{array}$ \\
\hline Agricultura & 107.794 & $0,62 \%$ & 242.729 & $0,65 \%$ \\
\hline Pecuária & 54.629 & $0,31 \%$ & 98.030 & $0,26 \%$ \\
\hline Pesca & 1.986 & $0,01 \%$ & 9.622 & $0,03 \%$ \\
\hline Indústria Extrativa Mineral & 487.384 & $2,79 \%$ & 936.161 & $2,51 \%$ \\
\hline Ind. de Transformação & 13.005 .429 & $74,40 \%$ & 25.729 .244 & $69,08 \%$ \\
\hline $\begin{array}{l}\text { Transformação de Minerais Não } \\
\text { Metálicos }\end{array}$ & 321.320 & $1,84 \%$ & 635.223 & $1,71 \%$ \\
\hline Metalurgia & 1.388 .811 & $7,95 \%$ & 3.028 .151 & $8,13 \%$ \\
\hline Mecânica & 1.704 .644 & $9,75 \%$ & 3.036 .896 & $8,15 \%$ \\
\hline $\begin{array}{l}\text { Material Elétrico, Eletrônico e } \\
\text { Comunicação }\end{array}$ & 1.394 .314 & $7,98 \%$ & 3.144 .299 & $8,44 \%$ \\
\hline Material de Transporte & 2.344 .432 & $13,41 \%$ & 3.702 .695 & $9,94 \%$ \\
\hline Madeira & 262.196 & $1,50 \%$ & 228.362 & $0,61 \%$ \\
\hline Celulose, Papel e Papelão & 373.981 & $2,14 \%$ & 764.077 & $2,05 \%$ \\
\hline Borracha & 384.913 & $2,20 \%$ & 934.904 & $2,51 \%$ \\
\hline Química & 2.435 .781 & $13,93 \%$ & 5.054 .078 & $13,57 \%$ \\
\hline $\begin{array}{l}\text { Produtos Medicinais, Farmacêuticos } \\
\text { e Veterinários }\end{array}$ & 722.387 & $4,13 \%$ & 1.626 .854 & $4,37 \%$ \\
\hline Têxtil & 369.365 & $2,11 \%$ & 551.673 & $1,48 \%$ \\
\hline $\begin{array}{l}\text { Vestuário, Calçados e Artefatos de } \\
\text { Tecidos }\end{array}$ & 101.773 & $0,58 \%$ & 267.184 & $0,72 \%$ \\
\hline Produtos Alimentícios Diversos & 765.319 & $4,38 \%$ & 1.682 .947 & $4,52 \%$ \\
\hline Bebidas & 98.346 & $0,56 \%$ & 158.193 & $0,42 \%$ \\
\hline Fumo & 137.037 & $0,78 \%$ & 269.010 & $0,72 \%$ \\
\hline Editorial e Gráfica & 33.098 & $0,19 \%$ & 94.601 & $0,25 \%$ \\
\hline Outras Indústrias & 167.712 & $0,96 \%$ & 550.097 & $1,48 \%$ \\
\hline Serviços Utilidade Pública & 44.170 & $0,25 \%$ & 63.531 & $0,17 \%$ \\
\hline Outros Serviços & 3.425 .481 & $19,60 \%$ & 9.258 .390 & $24,86 \%$ \\
\hline Outras Atividades & 353.158 & $2,02 \%$ & 905.705 & $2,43 \%$ \\
\hline Total Geral & 17.480 .031 & $100,00 \%$ & 37.243 .412 & $100,00 \%$ \\
\hline
\end{tabular}

(1) Inclui investimentos em Bolsa (DL 1.401) e Investimentos Incentivados (Res. 480, de 20.06.78)

Moedas convertidas em US\$, às paridades vigentes no último dia útil do ano

Fonte: Banco Central do Brasil. Elaboração própria

Chama atenção a manutenção da indústria de transformação enquanto principal componente do estoque de capital estrangeiro no país durante o período. Percebe-se, contudo, uma forte tendência decrescente da participação percentual desse setor no fluxo total de IDE. O estoque de capital estrangeiro no setor saltou de aproximadamente US\$ 13 bilhões em 1980 (74,4\% do total) para US\$25,7 bilhões em 1990 (69,08\% do total) e US\$28,9 bilhões em 1994 (51,2\% do total). A perda relativa de participação da indústria de transformação no estoque total de IDE no 
país deu-se concomitantemente à elevação do item outros serviços ${ }^{5}$. O estoque de capital desse setor que, em 1980, era de US\$3,42 bilhões (19,6\% do total) alcançou em 1990 a cifra de US\$ 9,25 bilhões (24,86\% do total)

A análise da evolução do setor "outros serviços", realizada a partir dos dados apresentados na Tabela 2, esclarece alguns aspectos importantes do tema.

Tabela 2

Evolução do estoque de IDE no setor "outros serviços"

\begin{tabular}{l|c|c|c|c|c|c}
\hline Subsetor & $\begin{array}{c}\text { Dez/ } \\
1980\end{array}$ & $\begin{array}{c}\% \text { do } \\
\text { Setor }\end{array}$ & $\begin{array}{c}\% \text { dDE } \\
\text { total }\end{array}$ & $\begin{array}{c}\text { Dez/ } \\
1990\end{array}$ & $\begin{array}{c}\% \text { do } \\
\text { setor }\end{array}$ & $\begin{array}{c}\text { IDE } \\
\text { total }\end{array}$ \\
\hline Bancos & 544.834 & $15,91 \%$ & $3,12 \%$ & 1.644 .445 & $17,76 \%$ & $4,42 \%$ \\
\hline Comércio Imobiliário & 107.171 & $3,13 \%$ & $0,61 \%$ & 160.522 & $1,73 \%$ & $0,43 \%$ \\
\hline $\begin{array}{l}\text { Comércio em Geral, } \\
\text { Importação e Exportação }\end{array}$ & 640.372 & $18,69 \%$ & $3,66 \%$ & 1.538 .489 & $16,62 \%$ & $4,13 \%$ \\
\hline $\begin{array}{l}\text { Companhia de Seguros } \\
\text { Consultoria, Representações } \\
\text { e Administração de Bens }\end{array}$ & 1.797 .565 & $52,48 \%$ & $10,28 \%$ & 4.920 .374 & $53,15 \%$ & $13,21 \%$ \\
\hline $\begin{array}{l}\text { Outras Instituições } \\
\text { Financeiras }\end{array}$ & 27.080 & $0,79 \%$ & $0,15 \%$ & 586.129 & $6,33 \%$ & $1,57 \%$ \\
\hline $\begin{array}{l}\text { Serviços Técnicos e } \\
\text { Auditoria }\end{array}$ & 201.264 & $5,88 \%$ & $1,15 \%$ & 233.428 & $2,52 \%$ & $0,63 \%$ \\
\hline \begin{tabular}{l} 
Turismo \\
\hline
\end{tabular} & 20.358 & $0,59 \%$ & $0,12 \%$ & 56.401 & $0,61 \%$ & $0,15 \%$ \\
\hline
\end{tabular}

Inclui investimentos em Bolsa (DL 1.401) e Investimentos Incentivados (Res. 480, de 20.06.78)

Moedas convertidas em US\$, às paridades vigentes no último dia útil do ano

Fonte: Banco Central do Brasil. Elaboração própria.

A análise da evolução do setor "outros serviços", realizada a partir dos dados apresentados na Tabela 2, esclarece alguns aspectos importantes do tema. No que tange ao comportamento do setor "outros serviços", merece destaque o comportamento dos subsetores de Consultoria, Representações e Administração de Bens, Bancos e Comércio em Geral, Importação e Exportação. Nesse sentido, vale a pena destacar que o setor de Consultoria, Representações e Administração de Bens já detinha em 1990 cerca de 13,2\% do estoque de capital estrangeiro no país, participação superior a verificada, por exemplo, pelo setor de transportes, símbolo da participação estrangeira na fase de industrialização pesada da indústria brasileira.

(5) O setor denominado "outros serviços" é composto por: Bancos, Comércio Imobiliário, Comércio em Geral, Importação e Exportação, Companhia de Seguros, Consultoria, Representações e Administração de Bens, Outras Instituições Financeiras, Serviços Técnicos e Auditoria, Turismo, Outros. 
Dois elementos devem ser destacados sobre o avanço do setor "outros serviços" no estoque total de capital produtivo durante os anos 1980. Em primeiro lugar, o fenômeno marca uma alteração relevante no padrão de inserção do capital produtivo estrangeiro no Brasil. Entre 1955-1980, seguindo entre outros Possas (1983), o capital estrangeiro em sua forma direta concentrou suas inversões na indústria manufatureira com destaque para sua participação nos setores dinâmicos do paradigma tecnológico metalmecânico-químico. Em certo sentido, a perda relativa de importância da indústria de transformação e a retomada da importância do setor de serviços nos anos 1980 refletem um retorno dos interesses do capital estrangeiro ao padrão verificado pré-industrialização pesada da economia brasileira ${ }^{6}$.

Em segundo lugar, é importante notar que a tendência de perda relativa dos investimentos estrangeiros nas atividades industriais e o concomitante aumento da participação do setor de serviços verificada nos anos 1980 foi aprofundada a partir de meados dos anos 1990. A observação da evolução dos fluxos do capital estrangeiro deixa claro esse ponto. Enquanto em 1981, aproximadamente $71 \%$ dos fluxos de IDE dirigiam-se para atividades industriais, em 1991, apenas 32\% dos fluxos de IDE dirigiram-se para tais atividades. A tendência foi apenas agravada durante a segunda metade dos anos 1990. Em 1998, por exemplo, apenas 11,89\% dos fluxos de IDE advinham de atividades industriais. Ao mesmo tempo, observa-se o crescimento dos fluxos no setor de serviço. Enquanto em 1981 o setor de serviços respondia por aproximadamente $26 \%$ dos fluxos de IDE para o país, em 1991, este setor já respondia por $76 \%$ dos IDEs. Finalmente, em 1998, o setor de serviços já concentrava $87,5 \%$ dos fluxos de investimentos estrangeiros no país.

Outro elemento que deve ser destacado, ainda que as informações a respeito do processo sejam escassas, diz respeito ao que Canuto (1993) chamou de "financeirização" dos IDEs. De acordo com o autor, aproximadamente 59\% dos IDEs na economia brasileira no período 1985-1989 deram-se por meio da conversão de dívidas em ações, "tratando-se, portanto, de uma parcial reconversão patrimonial de recursos já presentes naquela economia" (Canuto, 1993, p. 10).

A entrada de investimentos estrangeiros diretos em fusões e aquisições é outro elemento desse processo. Pesquisa realizada pela consultoria Price Waterhouse publicada pelo jornal Gazeta Mercantil ${ }^{7}$ registrou a ocorrência de 318 transações de fusões e aquisições e formação de joint-ventures no ano de 1995 no Brasil. De janeiro a maio de 1996, foram registrados 154 negócios, indicando um aumento de 54\% em

(6) Castro (1979) demonstrou que durante o longo período contido entre 1860-1933 os investimentos estrangeiros no país concentraram-se nas atividades de serviços ligadas às atividades agroexportadoras do setor cafeeiro. É importante, no entanto, relativizar a comparação, já que as razões para a concentração dos IDEs em serviços entre 1860 e 1933 eram muito distintas daquelas que explicam o aumento da participação estrangeira entre 1980-1990.

(7) Publicado em 12 de junho de 1996. 
relação ao mesmo período de 1995 . Interessa destacar que tal crescimento em tais atividades encontra-se crescentemente associado ao investimento estrangeiro. Entre 1991-1992 ocorreram em média 250 transações por ano, sendo a participação do capital estrangeiro responsável por $34 \%$ das fusões/aquisições e cerca de $62 \%$ da formação de joint ventures. Essa participação saltou para 48\% e 78\% em 1995, de acordo com a pesquisa da consultoria.

Em grande medida, o comportamento do IDE no período analisado pode ser entendido como fruto da conjunção de condições domésticas e externas, tal como proposto por Castro (1979) e Possas (1983). No plano doméstico, os anos 1980 foram marcados, como discutido acima, por uma profunda crise econômica especialmente concentrada nas atividades industriais. Já, no plano externo, o período foi marcado pela expansão dos fluxos de IDE em escala global. O fato de o Brasil ter permanecido praticamente à margem desse processo de expansão dos fluxos de IDE (no período deve ser interpretado como resultado, em alguma medida, das condições domésticas e externas de acumulação.

No plano internacional, a primeira observação a ser realizada é que o processo de expansão dos fluxos de IDE do período, de acordo com Chesnais (1996), deu-se de forma desigual, com significativa concentração desses fluxos intratríade e redução dos investimentos nos países em desenvolvimento. De acordo com dados de Coutinho e Ferraz (1995), a parcela do IDE direcionada aos países em desenvolvimento reduziu-se de $26,4 \%$ do total para $17,4 \%$ entre $1980 / 85$ e 1990. Assim, ainda que o contexto geral seja de forte expansão dos fluxos de IDE, é necessário destacar a redução da importância relativa dos países em desenvolvimento na absorção de tais investimentos.

Para Coutinho e Ferraz (1995), o processo decorre, entre outros fatores, de uma alteração nos determinantes dos investimentos diretos, com destaque para a ênfase crescente nas "vantagens competitivas locais". De acordo com os autores:

Em resumo, muito embora os obstáculos ao comércio externo ainda funcionem como indutores dos investimentos diretos das transnacionais, é crescente a ênfase nas vantagens competitivas locais. Essas vantagens há muito deixaram de ser estáticas (dotação de fatores) e cada vez mais são vantagens comparativas deliberadamente construídas, de natureza dinâmica, decorrentes de políticas públicas, da configuração sociocultural (fatores sociais) e da aptidão de parceiros locais... A atração de investimentos estrangeiros, especialmente os de maior conteúdo tecnológico, passou a ser objeto de intensa competição, através da oferta de condições e de vantagens competitivas construídas (Coutinho; Ferraz, 1995, p. 73).

Em síntese, o período analisado foi marcado por um conjunto de alterações nos determinantes dos IDEs que contribuíram para a redução da atratividade de países em desenvolvimento, tais como o Brasil. 
As condições internas de acumulação também jogaram um papel relevante para explicar o comportamento dos IDEs no período. O baixo crescimento da economia e a profunda instabilidade gerada pelo crônico processo inflacionário contribuíram para a redução dos fluxos de IDE ao país. Além desses elementos mais gerais, é necessário aprofundar a discussão sobre a dinâmica interna de acumulação, em especial, a discussão sobre a "estratégia de ajuste defensivo do patrimônio" implementada pelas grandes empresas na década de oitenta ${ }^{8}$.

Em sua essência, a "estratégia de ajuste defensivo" foi pautada pela combinação, em diversos graus, de uma redução no volume dos investimentos produtivos - dado o cenário de retração do mercado e a elevada instabilidade concomitantemente à ampliação dos ganhos de natureza financeira e a implementação - para os grupos empresariais com poder de mercado - de políticas de aumento das margens de lucro. A utilização da citada estratégia, no contexto da crise dos anos 1980, foi possível em função de algumas características da economia brasileira. De certa forma, o elevado grau de fechamento da economia combinado com o poder de mercado dos grandes grupos empresariais gerava as condições necessárias para a promoção de uma política de elevações das margens de lucro. Finalmente, a política macroeconômica de manutenção de elevadas taxas de juros reais domésticas gerava as condições necessárias para a ampliação dos ganhos de natureza financeira.

Gonçalves (1993) argumenta, como discutido na seção 2, que a queda nos IDEs nos anos 1980 é igualmente o reflexo de uma estratégia de "ajuste defensivo" empreendida pelas EMNs. De acordo com o autor, o elevado grau de permissividade do mercado doméstico e a política macroeconômica caracterizada pela manutenção de elevadas taxas de juros permitiram que as EMNs empreendessem um ajuste similar ao promovido pelas empresas nacionais. A possibilidade de ajuste nos markups - dado o elevado poder de mercado das EMNs - e o aumento da parcela dos lucros derivados de operações financeiras foram os responsáveis pela manutenção de níveis elevados de rentabilidade em um contexto de contração dos fluxos de novos investimentos ${ }^{9}$.

Outro elemento importante da discussão diz respeito à elevação da importância dos IDEs no setor de serviços na década de 1980 e primeira metade dos anos 1990. A observação das condições internas e externas ajuda também a entender esse processo. No plano doméstico, cabe ressaltar, tal como discutido ao longo do trabalho, que a crise dos anos 80 foi especialmente grave para a indústria brasileira.

(8) Para uma discussão sobre o tema, recomenda-se a leitura de Almeida e Novais (1991)

(9) Esses elementos dão conta da descrição geral do fenômeno e ajudam a explicar o contexto de queda global dos IDEs no período. O argumento, no entanto, não esgota a discussão. Como analisado na seção 2, o trabalho de Cunha (1995), por exemplo, destaca a existência de comportamentos distintos à lógica do "ajuste defensivo". O tipo de análise, que incorpora aspectos microeconômicos e a dimensão setorial, ainda que reconhecidamente relevante, vai além dos objetivos deste trabalho. 
A perda de importância relativa das atividades industriais e o crescimento das atividades ligadas ao setor de serviços marcaram o período. De acordo com Nassif (2008), a participação da indústria no PIB recuou de 32\% para 22,7\% entre 1986 e 1990. No mesmo período, a participação do setor de serviços no produto saltou de $45 \%$ para $60 \%$. As evidências disponíveis sugerem, portanto, que na década de 80 , as condições internas foram mais favoráveis ao desenvolvimento do setor de serviços.

As razões para a gravidade da crise na indústria e sua perda de importância relativa na geração do produto extrapolam os objetivos deste trabalho. Alguns elementos, não obstante, podem ser destacados como importantes para discussões mais profundas sobre o tema. É necessário lembrar que o processo de industrialização brasileiro foi o resultado de uma clara "divisão do trabalho" entre o capital privado nacional, o capital estrangeiro e o Estado. O colapso financeiro desse último no início dos anos 1980 limitou substancialmente a possibilidade de expansão da infraestrutura econômica e da indústria de insumos básicos, elementos fundamentais para a expansão dos investimentos privados (nacionais e estrangeiros) no setor industrial.

Finalmente, é interessante destacar que o período em análise foi marcado por profundas transformações no setor produtivo que acarretaram - segundo Coutinho e Ferraz (1995) - elevações substanciais das barreiras financeiras e tecnológicas no setor industrial, especialmente nos setores dinâmicos do novo paradigma tecnológico.

Assim, a crise financeira do Estado - dada sua relevância histórica no processo de industrialização - e as profundas alterações das atividades produtivas, com destaque para a ampliação das barreiras financeiras e tecnológicas nas atividades industriais são elementos que devem ser levados em consideração para entender as razões da retração mais pronunciada das atividades industriais na década de 1980 . Do ponto de vista dos objetivos do trabalho, a discussão deixa evidente a relevância do contexto interno para entender o comportamento dos IDEs no país.

Em síntese, a discussão promovida nesta seção sustenta que a análise das condições internas e externas de acumulação é relevante para entender aspectos essenciais dos movimentos do capital estrangeiro em sua forma produtiva no país.

\section{IDE no Brasil e o Balanço de Pagamentos (1980-1994)}

Um último aspecto importante a ser analisado refere-se à representatividade do IDE no desempenho do Balanço de Pagamentos do Brasil entre a década de 1980 e 1994. O Gráfico 4 apresenta o saldo em Transações Correntes (TC), Conta Capital e Financeira (CC) e o volume de Investimento Estrangeiro Direto (IDE) na economia brasileira entre 1970 e 1994. Os dados têm início em 1970 para demonstrar o processo de deterioração das contas externas brasileiras ao longo da década de 
1970 que culminaram em alguns dos problemas discutidos nas seções anteriores, a respeito do plano doméstico, com destaque para endividamento externo e déficit crescente em TC.

Gráfico 4

Balanço de pagamentos: transações correntes, conta capital e financeira e IDE (1970-1994)

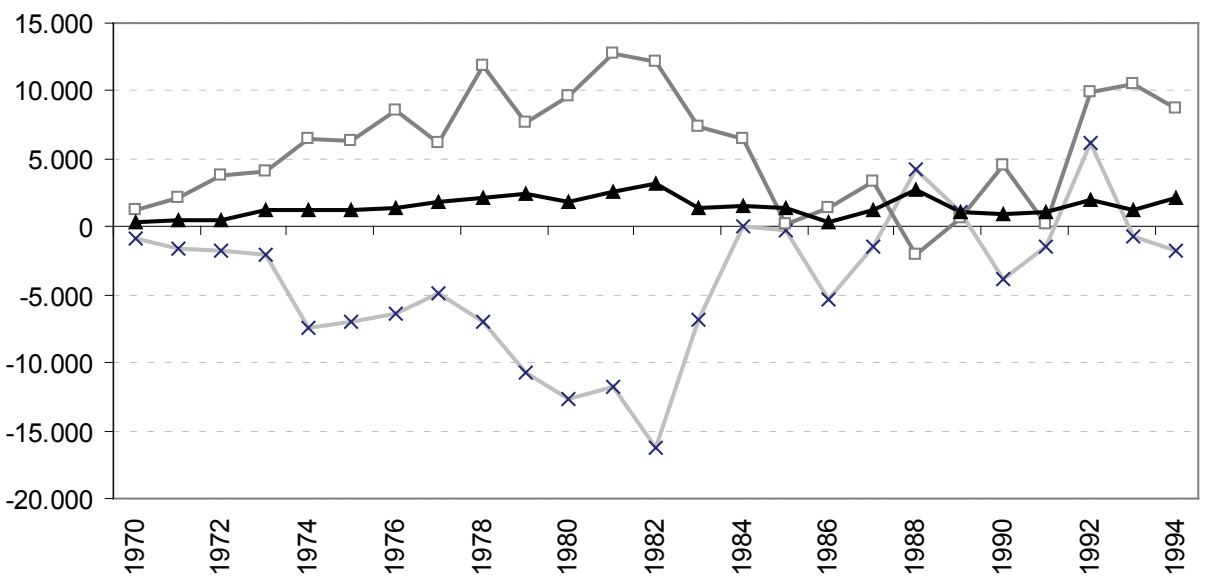

$\times$ TRANSAÇÕES CORRENTES $\quad \square-$ CONTA CAPITAL E FINANCEIRA $\quad \longrightarrow$ Investimento estrangeiro direto

Fonte: Elaboração própria com base em Banco Central do Brasil (2010).

Com relação ao IDE, observa-se uma tendência de expansão ao longo da década de 1970, a qual é interrompida em 1983, apresentando uma relativa estagnação entre 1980 e 1994, com exceção do período entre 1987 e 1988, já ressaltado anteriormente. O Gráfico 2 demonstra que, apesar de cumprir um papel importante no processo de industrialização até o início da década de 1980, conforme discutido por Curado e Cruz (2008), o volume de IDE ficou longe de ser suficiente para compensar o déficit em TC no período.

Ademais, a década de 1980 também marca um momento de expansão da remessa de lucro para o exterior, em função dos IDEs acumulados no período anterior. O Gráfico 3 apresenta o resultado da "Renda de Investimentos" que é parte da conta Serviços e Rendas / Transações Correntes. Observa-se que já, a partir da segunda metade da década de 1970, há uma tendência à expansão do saldo negativo advindo da renda de investimento estrangeiro direto. Fica claro, contudo, que o principal componente na contribuição do resultado deficitário em TC foi o pagamento de juros. 
Gráfico 5

Balanço de pagamentos: conta renda de investimentos (1970-1994)

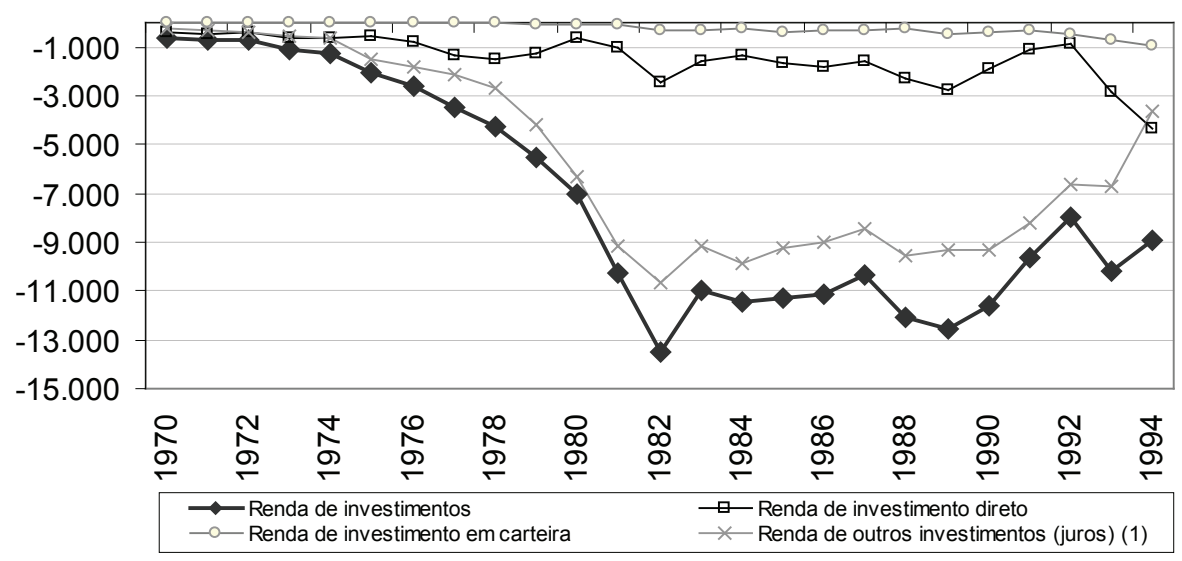

(1) Até 1981, o total de juros foi considerado como rendas de outros investimentos. A partir de 1982, foi distribuído em investimento direto (empréstimo intercompanhia), investimento em carteira (títulos de renda fixa) e outros investimentos.

Fonte: Elaboração própria com base em Banco Central do Brasil (2010).

Com relação, portanto, aos efeitos do IDE sobre o resultado do Balanço de Pagamentos do Brasil entre 1980 e 1994, observa-se que o volume do IDEs foi pouco representativo com relação à magnitude do déficit em TC acumulado ao longo da década de 1970 e ainda presente no início dos anos 1980. Adicionalmente, o IDE acumulado até então aumentou a pressão sobre o déficit em TC, por meio da renda emitida ao exterior. Esse cenário foi alterado no final da década de 1990, mais especificamente a partir de 1998, quando a entrada de IDE foi suficiente para compensar o desequilíbrio nas TCs.

Em tal caso, é interessante perceber que o período entre 1980 e 1994 marca também um momento de transição importante com relação ao papel do IDE na economia brasileira.

\section{Considerações finais}

Este artigo discutiu a evolução do IDE no Brasil entre os anos de 1980 e 1994, fase em que a economia brasileira foi marcada pela redução do ritmo de atividade econômica e o descontrole do processo inflacionário. É interessante notar como o capital produtivo estrangeiro alterou, de forma rápida, sua estratégia de inserção a partir do agravamento da crise doméstica no início dos anosn1980. Foi quando também ocorreu uma contenção de liquidez e reordenamento dos fluxos financeiros internacionais, por conta dos respectivos choques no preço do petróleo promovidos pelos países da OPEP ao longo da década de 1970. 
A perda de importância relativa das atividades industriais ocorreu em um momento especial do cenário doméstico e internacional. Conforme anteriormente discutido, os anos 1980 foram marcados pela consolidação do Complexo Eletrônico enquanto eixo dinâmico da atividade industrial em um contexto de mudança do paradigma tecnológico. A alteração dos interesses estrangeiros no país ocorreu, portanto, em um momento singular do processo de desenvolvimento. Ao mesmo tempo, a indústria brasileira passou por um longo período de estagnação econômica, seguido de um processo de adaptação por conta da abertura comercial promovida a partir do início da década de 1990.

O ponto a ser ressaltado é a década de 1980, marcada pela desarticulação da "divisão do trabalho", fundamental no processo de industrialização brasileiro. Entre 1955 e 1980, a "divisão do trabalho" entre capital privado nacional, capital privado estrangeiro e o Estado estava bem definida. Ao último, cabiam os investimentos nos setores de infraestrutura econômica, com maiores volumes de inversão e elevados prazos de maturação. Ao segundo, cabia a instalação dos setores industriais dinâmicos do paradigma tecnológico metalmecânico-químico. Ao primeiro, as atividades ligadas à indústria de bens salário, de menor conteúdo tecnológico e volumes igualmente reduzidos de inversão.

A crise do Estado nos anos 1980 marcou o início do processo de declínio da participação estatal na produção de bens e serviços e na realização dos investimentos em infraestrutura. O capital privado de origem nacional, nesse contexto de profunda instabilidade e elevação do grau de incerteza do ambiente econômico, procurou fazer um ajuste patrimonial, com notória postergação/cancelamento de investimentos produtivos. O capital produtivo de origem estrangeira seguiu as tendências endogenamente determinadas pela economia brasileira, particularmente no que se refere ao volume de tais investimentos. Por seu turno, a elevação da participação dos fluxos de IDE em setores de serviços e o processo de "financeirização" do IDE refletem tendências do movimento do capital produtivo em nível global.

São lições importantes do período analisado. Ainda que as condições internacionais - especificamente a ampliação dos fluxos de capital produtivo tenham sido extremamente favoráveis, o comportamento do IDE reflete em grande medida às condições internas de acumulação. Estratégias de desenvolvimento centradas na entrada de IDE podem, portanto, estar fadadas ao fracasso quando as condições internas de funcionamento da economia forem desfavoráveis, mesmo que o contexto internacional, no que tange aos movimentos do capital produtivo, seja francamente positivo.

Essa lição histórica é negligenciada em diversas ocasiões. Franco (1998), por exemplo, credita à expansão dos IDEs um papel fundamental na ampliação da produtividade nos anos 1990, peça chave na ampliação da competitividade 
externa da economia brasileira. O autor, não obstante, negligencia a importância do cenário doméstico, em franca retração a partir de 1997, na definição das decisões de investimento do capital produtivo externo. O comportamento dos IDEs na década de 1980 fornece um exemplo histórico claro dos limites de estratégias de crescimento baseadas na expansão do capital produtivo estrangeiro. Via de regra, tais investimentos são atraídos pela expansão do mercado local e têm poder bastante limitado na indução do crescimento como já argumentado por Laplane e Sarti (1997).

Em suma, este artigo procurou analisar o papel do IDE no Brasil durante o período de alta inflação, especialmente na década de 1980. Um elemento de destaque é que a década de 1980 não foi marcada apenas pela já tão discutida "crise do Estado" e desarticulação dos investimentos do capital privado nacional. Os anos 1980 também foram marcados pela "quebra" da outra "pata do tripé" que caracterizou o desenvolvimento industrial brasileiro entre 1955-1980, elemento que, além de aprofundar a crise dos anos 1980, também contribuiu para a ampliação do gap tecnológico entre o país e o resto do mundo, dada a relevância histórica do IDE em setores tecnologicamente dinâmicos.

\section{Referências bibliográficas}

ALMEIDA, J. S. G.; NOVAIS, L. F. A empresa líder na economia brasileira: ajuste patrimonial e tendências do mark-up. São Paulo: IESP/Fundap, 1991.

BAER, M. Mudanças e tendências dos mercados financeiros internacionais na década de oitenta. Pensamento Iberoamericano, n. 18, jul./dez. 1990.

BANCO CENTRAL DO BRASIL. Reformas do sistema monetário brasileiro. Disponível em: <www.bc.gov.br>. Acesso em: 30 maio 2010.

BIELSCHOWSKY, R. Transnational corporations and the manufacturing sector in Brazil. Santiago, Chile, 1992.

BNDES. O capital estrangeiro na indústria brasileira: atualidade e perspectiva. Rio de Janeiro, 1988. (Texto para Discussão).

BOLETINS DO BANCO CENTRAL DO BRASIL. Diversos números.

CANTWELL J. A survey of theories of international production In: PITELIS, C.; SUGDEN, R. (Org.). The nature of the transnational firm. London: Routledge, 1990.

CANUTO, O. Investimento estrangeiro direto e restruturação industrial. Campinas: Unicamp. Instituto de Economia, 1993. (Texto para Discussão, n, 27).

CARDOSO DE MELLO, J. M. O capitalismo tardio. São Paulo, Brasiliense, 1982.

CARNEIRO, D. D. Crise e esperança: 1974-1980. In ABREU, M. P. (Org.). A ordem do progresso. Rio de Janeiro: Editora Campus [1990].

; MODIANO, E. Ajuste externo e desequilíbrio interno: 1980-1984. In: ABREU,

M. P. (Org.). A ordem do progresso. Rio de Janeiro: Editora Campus [1990]. 
CASTRO, A. C. As empresas estrangeiras no Brasil (1860-1913). São Paulo: Zahar Editores, 1979.

CHESNAIS, F. A mundialização do capital. São Paulo: Xamã, 1996.

COUTINHO, L. A terceira Revolução Industrial e tecnológica: as grandes tendências de mudança. Economia e Sociedade, Campinas, n. 1, ago. 1992.

; BELluZZO, L. G. M. Política econômica, inflexões e crise: 1974/1981. In: BELluZZO, L. G. M.; COUTINHO, R. (Org.). Desenvolvimento capitalista no Brasil ensaios sobre a crise. Campinas: Unicamp, 1982. v. 1.

; FERRAZ, J. C. Estudo da Competitividade da Indústria Brasileira. 3. ed. Campinas: Editora da Universidade Estadual de Campinas, 1995.

CUNHA, A. M. Estratégias de empresas transacionais na economia brasileira nos anos 80 e 90. Dissertação (Mestrado)- Unicamp. Instituto de Economia, 1995.

CURADO, M. L.; CRUZ, M. J. V. Investimento Direto Externo e industrialização no Brasil. Revista de Economia Contemporânea, Rio de Janeiro, v. 12, n. 3, 2008.

DUNNING, J. H. Explaining changing patterns of international production: in defense of the ecletic theory. Oxford Bulletin of Economics and Statistics, v. 41, n. 4, Nov. 1979.

. The ecletic paradigm of international prodution: a restatement and some possible extensions. International Business Studies, v. XIX, n. 1, Spring, 1988.

FAJNZYLBER, F. Industrializacion en América Latina: de la caja negra al casilero vacio. Cuadernos de La Cepal, Santiago, Chile, n. 60, 1989.

FRANCO, G. A inserção externa e o desenvolvimento. Revista de Economia Política, São Paulo, v. 18, n. 3, jul./set. 1998.

FRITSCH, W.; FRANCO, F. O Investimento Direto Estrangeiro em uma nova estratégia industrial. Revista de Economia Política, São Paulo, v. 9, n. 2, 1989.

GAZETA MERCANTIL. Edição de 12 de junho de 1996.

GONÇALVES, R. Estratégias dos oligopólios mundiais nos anos 90 e oportunidades para o Brasil. Nota Técnica Temática do Bloco: Condicionantes Internacionais da Competitividade. Estudo da Competitividade da Indústria Brasileira, 1993.

HYMER, S. International operations of national firms. A study of direct investiment. Thesis (PHD)-MIT, 1976.

LAPLANE, M. O complexo eletrônico na dinâmica industrial dos anos 80. Tese (Doutorado)Unicamp. Instituto de Economia, 1992.

; SARTI, F. Investimento Direto Estrangeiro e a retomada do crescimento

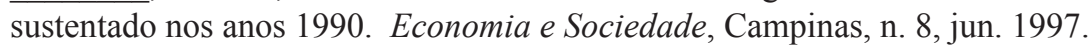

et al. Empresas transnacionais no Brasil nos anos 90: fatores de atração, estratégias e impactos. In: CHUDNOVSKY, D. (Org.). El boom de inversión extranjera directa en el Mercosur. Buenos Aires: Siglo Veintiuno de Argentina Editores, 2001.

MATTOS, L. B.; CASSUCE, F. C. C; CAMPOS, A. C. Determinantes dos Investimentos Diretos Externos no Brasil, 1980-1994. Revista de Economia Contemporânea, Rio de Janeiro, v. 11, n. 1, jan./abr. 2007. 
MODIANO, E. A ópera dos três cruzados: 1985-1989. In: ABREU, M. P. (Org.). A ordem do progresso. Rio de Janeiro: Editora Campus, 1990.

NASSIF, A. Há evidências de desindustrialização no Brasil? Revista de Economia Política, São Paulo, v. 28, n. 1, jan./mar. 2008.

NONNENBERG, M. J. B. Determinantes dos Investimentos Externos e impactos das empresas multinacionais no Brasil - as décadas de 70 e 90. Instituto de Pesquisas Econômicas Aplicadas, IPEA. agosto, 2003. (Texto para Discussão, n. 969).

OLIVEIRA, G. O Brasil Real: desafios da pós-estabilização na virada do milênio. São Paulo: Editora Mandarim, 1996.

POSSAS, M. L. Multinacionais e industrialização no Brasil. In: BELLUZO, L. G. M.; COUTINHO, R. Desenvolvimento capitalista no Brasil: ensaios sobre a crise. 2. ed. São Paulo: Brasiliense, 1983.

SARTI, F.; LAPLANE, M. F. Investimento estrangeiro direto e a internacionalização da economia brasileira nos anos 1990. Economia e Sociedade, Campinas, v. 11, n. 1 (18), jan./ jun. 2002.

SUZIGAN, W. A indústria brasileira após uma década de estagnação: questões para a política industrial. Economia e Sociedade, Campinas, v. 1, n. 1, 1992.

TAVARES, M. C. Acumulação de capital e industrialização no Brasil. Tese (Livre Docência) -UFRJ, 1975.

Ajuste e reestruturação nos países centrais: a modernização conservadora. Economia e Sociedade, Campinas, v. 1, n. 1, 1992.

WILLIAMSON, O. E. Markets and hierarchies: analysis and antitrust implications. New York: Free Press, 1975. 